\title{
PENGARUH DIFFERENTIATION, SATISFACTION DAN QUALITY TERHADAP WORD OF MOUTH MARKETING PADA MAHASISWA DI PERGURUAN TINGGI SWASTA JAKARTA BARAT
}

\author{
Zahrida Zainal wiryawan ${ }^{1}$ \\ Nur Hidayah ${ }^{2}$ \\ ${ }^{1}$ Jurusan manajemen, Universitas Tarumanagara Jakarta \\ Email:zahridaw@fe.untar.ac.id \\ ${ }^{2}$ Jurusan manajemen, Universitas Tarumanagara Jakarta \\ Email: nuridaumarudin@gmail.com
}

\begin{abstract}
Abstrak
Tujuan penelitian ini adalah untuk mengetahui pengaruh differentiation, satisfaction dan quality terhadap word of mouth marketing pada mahasiswa. Mahasiswa yang diteliti sebanyak 250 di lima Universitas di Jakarta Barat. Pengumpulan data dengan menyebarkan kuesioner dan di analisis secara deskriptif, regresi dengan uji $\mathrm{F}$ dan $\mathrm{t}$. Hasil riset menunjukkan bahwa, secara menyeluruh menunjukkan hasil yang signifikan, artinya terdapat pengaruh secara simultan antara differentiation, satisfaction dan quality terhadap word of mouth. Melalui uji t secara individu masing-masing variabel juga terdapat hasil yang signifikan artinya differentiation, satisfaction dan quality berpengaruh terhadap word of mouth pada mahasiswa. Hasil penelitian ini dapat memberikan informasi bahwa penting untuk mengetahui differentiation, satisfaction dan quality bagi suatu perguruan tinggi karena dapat mempengaruhi word of mouth pada mahasiswa. Differentiation, satisfaction dan quality yang dimiliki perguruan tinggi dapat mendorong kegiatan promosi sehingga meningkatkan minat bagi masyarakat untuk memilih suatu perguruan tinggi .
\end{abstract}

Kata kunci: differentiation, satisfaction, quality, word of mouth

\section{Abstract}

The objective of this study was to investigate the influence of differentiation, satisfaction and Quality on the word of mouth marketing in the private university students in West Jakarta. The number of the students in this study was 250 students studied at five University of West Jakarta. Data collection was conducted by distributing questionnaires, which was then descriptively and regressively analyzed using the F-test and t-test.The research results show that, through the F-test, the results were significant meaning that there was simultaneous influence between differentiation, satisfaction and quality on the word of mouth marketing in the students. Using the t-test, each variable individually has been found to be significant, in that the differentiation, satisfaction and Quality on the word of mouth marketing in the students. It is anticipated that, through this research, some information could be revealed about the importance of the presence of differentiation, satisfaction and quality for a college because it can affect word of mouthon the students so as to encourage the promotion of activities that can improve the specialization for the people to choose a college.

Key words: differentiation, satisfaction and quality on the word of mouth marketing

\section{PENDAHULUAN}

Masyarakat saat ini memiliki akses informasi dan komunikasi dengan intensitas tinggi, berbagai cara diterapkan oleh institusi pendidikan tinggi untuk mendapatkan calon mahasiswa yang baik secara kualitas maupun kuantitas. Beragam kegiatan promosi yang dilakukan untuk mempromosikan program yang dimiliki kepada calon mahasiswa. Hal ini bertujuan untuk meningkatkan penerimaan mahasiswa baru.

Cara untuk mempromosikan program universitas ada yang memerlukan biaya besar seperti periklanan. Dan yang berbiaya kecil bahkan tanpa biaya yaitu word of mouth marketing. Sankatsing (2007) menyatakan bahwa belanja iklan di seluruh dunia melebihi 350.000.000.000 Euro dalam 1 tahun. Pembicaraan sosial menghasilkan lebih dari 3.3 miliar kesan merek setiap hari (Keller dan Libai, 2009 dalam Berger dan Schwartz 2011). Lembaga riset Nielsen 
menyatakan bahwa belanja iklan di Indonesia lebih dari Rp 87 triliun sepanjang 2012. Hal ini menunjukkan besarnya dana yang harus disediakan bila menjadikan iklan sebagai saluran promosi. Egli dan Gremaud (dalam Meiners, Schwarting dan Seeberger, ed., 2010) menyatakan bahwa pesan dari pemasaran tradisional menghadapi isu kredibilitas karena latar belakang komersial dan seringnya terjadi kesalahan komunikasi dalam menghubungkan karakteristik penjualan dengan konsumen. Fenomena ini mengindikasikan bahwa periklanan cenderung mengalami penurunan fungsi dalam upaya mempromosikan produk maupun jasa. Hal ini dibuktikan oleh The Nielsen Company yang melakukan internet based survey kepada 25.000 responden dari 50 negara.

Tabel 1.

Kepercayaan Konsumen Kepada Periklanan Berdasarkan Saluran

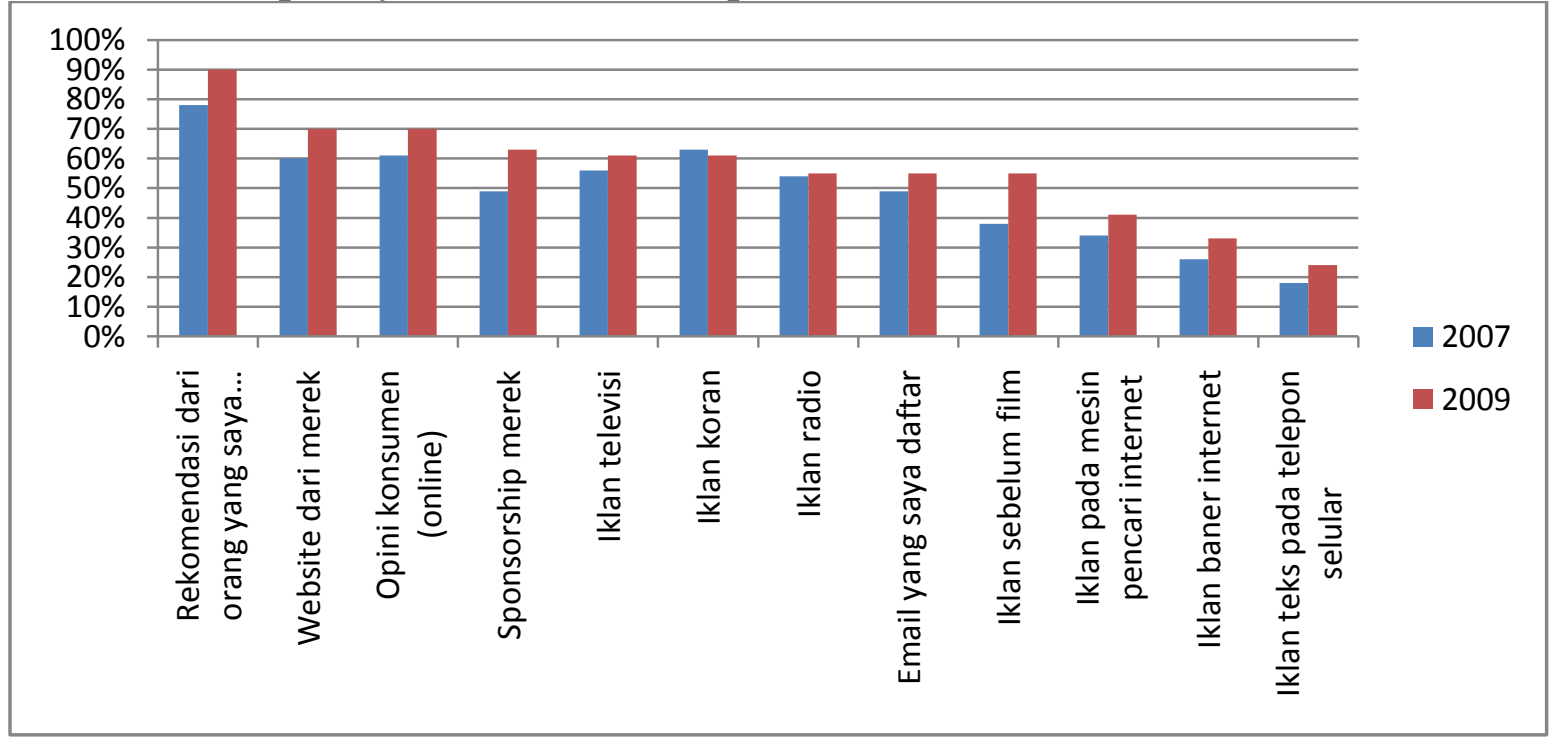

Sumber: The Nielsen Company (2009)

Dari tabel di atas dapat di lihat bahwa konsumen (mahasiswa dan calon mahasiswa) cenderung untuk mencari dan melengkapi informasi di luar sumber-sumber formal yaitu komentar atau rekomendasi dari orang yang mereka kenal. Calon mahasiswa akan terlibat dengan apa yang disebut dengan word of mouth marketing atau communication. Kozinets, Robert V (2010), Adrian (2011) mendefinisikan word of mouth sebagai komunikasi tatap muka mengenai brand, produk atau jasa di antara orang yang mengetahui atau merasakan yang tidak memiliki hubungan terhadap entitas komersial. Word of mouth adalah kekuatan dominan dalam pasar jasa (Mangold, Miller dan Brockway, 1999). Kunci keunggulan dari word of mouth dibandingkan dengan classical mass-marketing adalah daya tarik dan amanat dari individu konsumen (Meiners, Schwarting dan Seeberger, 2010).

Studi yang dilakukan US Office of Consumer Affairs mengindikasikan bahwa rata-rata satu konsumen yang tidak puas dapat diharapkan untuk memberitahu kepada sembilan orang lainnya mengenai pengalamannya. Konsumen yang puas akan memberitahukan rata-rata kepada lima orang lainnya (Knauer, 1992 dalam Mangold, Miller dan Broackway, 1999).Berdasarkan kajian di atas, maka yang menjadi masalah adalah : Apakah brand characteristics yang terdiri atas differentiation, quality dan satisfaction yang dimiliki oleh suatu perguruan tinggi secara 
PENGARUH DIFFERENTIATION, SATISFACTION DAN

QUALITY TERHADAP WORD OF MOUTH MARKETING

Z. Z. Wiryawan \& NurHidayah

PADA MAHASISWA DI PERGURUAN TINGGI SWASTA

JAKARTA BARAT

bersama-sama maupun parsial memiliki pengaruh terhadap pembentukan word of mouth marketing pada mahasiswa di Universitas Jakarta Barat

\section{Pembentukan Hipotesis}

Pengaruh Brand Characteristics (Differentiation, Quality dan Satisfaction) terhadap Word of Mouth Marketing

Word of mouth adalah salah satu media promosi yang harus diperhatikan oleh suatu perguruan tinggi dalam upaya memberi pengaruh kepada mahasiswa untuk merekomendasikan kepada calon mahasiswa atau memberikan pengaruh pada calon mahasiswa untuk mengambil suatu keputusan dalam memilih suatu universitas. Dwayne (2001), Buttle.(1998), Casielles, (2013). Lovett (2013) meneliti mengenai brand characteristic yang mempengaruhi word of mouth. Penelitian ini hubungan brand characteristics dengan word of mouth dengan mengeksekusi analisis empiris yang komprehensif dengan mengumpulkan data dari 697 brand yang paling sering dibicarakan di Amerika Serikat dari 16 kategori. Mereka membuat kerangka teoritis dengan mengklasifikasikan brand characteristic pada tiga faktor yang mempengaruhi word of mouth, yaitu sosial, emosional dan fungsional dan membedakannya dari saluran yaitu online dan offline. Hasil dari penelitian ini menunjukkan terdapat pengaruh yang positif dan signifikan dari brand characteristics pada word of mouth kecuali pada karakteristik kepuasan. Beberapa karakteristik memiliki perbedaan dalam pengaruh terhadap word of mouth dalam saluran word of mouth yang digunakan.

Christoph Fuchs dan Adamantios Diamantopoulos dalam jurnal berjudul evaluating the effectiveness of brand-positioning strategies from a consumer perspective tahun 2010 mengkasifikasikan tipe positioning. Tipe positioning yang berhubungan dengan karakter merek adalah features dan abstract, kedua fitur ini menjadikan brand characteristic sebagai pembentuk positioning. Mereka juga menyebutkan bahwa actual position dapat dilihat dalam word of mouth.

\section{HIPOTESIS}

Beberapa hipotesis dapat disusun sebagai berikut:

H1: Terdapat pengaruh yang signifikan secara bersama-sama antara differentiation,satisfaction dan quality terhadap word of mouth marketing pada suatu universitas

$\mathrm{H} 2$ : Terdapat pengaruh yang positif antara differentiation terhadap word of mouth marketing pada suatu universitas

H3 : Terdapat pengaruh yang positif antara satisfaction terhadap word of mouth marketing pada suatu universitas

H4 : Terdapat pengaruh yang positif antara quality terhadap word of mouth marketing pada suatu universitas

\section{METODOLOGI}

Penelitian ini dilakukan di beberapa perguruan tinggi di Jakarta Barat. Populasinya meliputi seluruh mahasiswa di suatu perguruan tinggi Jakarta Barat. Teknik pemilihan sampel yang digunakan dalam penelitian ini, yaitu teknik non propability sampling. Metode sampling yang digunakan untuk pengumpulan data dilapangan adalah purposive sampling,yaitu sampel diambil dengan maksud atau tujuan tertentu. Seseorang atau sesuatu diambil sebagai sampel karena peneliti menganggap bahwa seseorang atau sesuatu tersebut memiliki informasi yang diperlukan bagi penelitiannya. Responden diambil dari Fakultas Ekonomi yang dimiliki oleh lima 
Universitas di Jakarta Barat.Responden adalah mahasiswa minimal semester 6 saat pengumpulan data dilakukan. Setiap perguruan tinggi tersebut diambil kurang lebih 50 mahasiswa, sehingga jumlah sampel yang dipilih sebanyak 250 responden.

Variabel penelitian meliputi tiga variabel independen yaitu: variable differensiasi dengan contoh indikaor: Perbedaan pada percaya akan keunikan, pengembangan peminatan, keunggulan akademik, pengembangan potensi. Vaiabel Satisfaction dengan indicator : Secara keseluruhan puas, pelayanan sesuai harapan, pelayanan ideal. Variabel Quality dengan contoh indikator: keunggulan, bereputasi, fakultas terbaik, siswa terbaik dan sebagainya. Untuk dependen variable adalah Word of mouth dengan contoh indikator: .Dimana indikator dari masing masing variable disajikan pada tabel berikut: Cukup dikenal, Sering menjadi pembicaraan, kesempatan memberitau orang lain, membicarakan secara terus menerus dan sebagainya.

Teknik pengumpulan data penelitian ini dilakukan dengan memberikan sejumlah pertanyaan-pertanyaan dalam bentuk angket multiple choice kepada mahasiswa yang terpilih sebagai anggota sampel. Mahasiswa diminta memberikan jawaban atas sejumlah pertanyaanpertanyaan yang diajukan oleh peneliti atas tanggapannya tentang differensiasi, quality dan satisfaction terhadap word of mouth. Angket yang dipilih adalah Angket dengan range skala 1 sampai 10 dengan alternative tanggapannya untuk sangat tidak setuju (STS) sampai sangat setuju (SS).

\section{HASIL}

\section{Melalui Uji Validitas dan Reliabilitas}

Dari hasil pengujian diketahui bahwa hasil $\mathrm{KMO} \geq 0,6$ dengan loading $\geq 0,4$ sehingga butirbutir pernyataan adalah valid. Selanjutnya nilai alpha pada setiap butir-butir pertanyaan / pernyataan lebih besar dari 0,7, maka dapat dikatakan semua variabel adalah reliable.

\section{Uji Asumsi Terhadap Analisis Regresi Linier Ganda}

Terdapatn 4 kriteria untuk uji asumsi, yaitu normalitas, multikolinearitas, otokorelasi dan heteroskedastisitas menunjukkan model regresi layak digunakan

3. Analisis Pengaruh Differentiation, Satisfaction dan Quality terhadap Word of mouth marketing dapat dilihat pada hasil perhitungan dalam model summary, khususnya angka Adjusted $R$ square di bawah ini:

Tabel 1 Model Summary ${ }^{b}$

\begin{tabular}{|l|l|r|r|r|}
\hline Model & R & R Square & \multicolumn{1}{c|}{$\begin{array}{c}\text { Adjusted R } \\
\text { Square }\end{array}$} & $\begin{array}{l}\text { Std. Error of } \\
\text { the Estimate }\end{array}$ \\
\hline 1 &, $565^{\mathrm{a}}$ &, 319 &, 311 &, 54246 \\
\hline
\end{tabular}

a. Predictors: (Constant), Quality, Satisfaction, Differentiation

b. Dependent Variable: Word of Mouth Marketing

Sumber :Output SPSS dan diolah penulis

Untuk mengetahui apakah model regresi telah memenuhi syarat signifikansi atau belum, diperlukan pengujian koefisien jalur, seperti terlihat pada tabel berikut ini:

Tabel 2 ANOVA

\begin{tabular}{|ll|r|r|r|r|r|}
\hline \multicolumn{1}{|l|}{ Model } & Sum of Squares & Df & Mean Square & F & Sig. \\
\hline 1 & Regression & 33,936 & 3 & 11,312 & 38,441 &, $000^{\mathrm{a}}$ \\
& Residual & 72,390 & 246 &, 294 & & \\
Total & 106,326 & 249 & & & \\
\hline
\end{tabular}


PADA MAHASISWA DI PERGURUAN TINGGI SWASTA

JAKARTA BARAT

Tabel 2 ANOVA ${ }^{b}$

\begin{tabular}{|rl|r|r|r|r|r|}
\hline \multicolumn{1}{|l|}{ Model } & Sum of Squares & Df & Mean Square & F & Sig. \\
\hline 1 & Regression & 33,936 & 3 & 11,312 & 38,441 &, $000^{\mathrm{a}}$ \\
& Residual & 72,390 & 246 &, 294 & & \\
& Total & 106,326 & 249 & & & \\
\hline
\end{tabular}

a. Predictors: (Constant), Quality, Satisfaction, Differentiation

b. Dependent Variable: Word of Mouth Marketing

Sumber :Output SPSS dan diolah penulis

4. Pengaruh Differentiation, Satisfaction dan Quality terhadap Word of mouth marketing secara Parsial.

Besarnya pengaruh, digunakan angka Beta atau standardized coefficient di bawah ini:

Tabel 3. Coefficients

\begin{tabular}{|c|c|c|c|c|c|c|}
\hline \multirow{2}{*}{\multicolumn{2}{|c|}{ Model }} & \multicolumn{2}{|c|}{$\begin{array}{c}\text { Unstandardized } \\
\text { Coefficients }\end{array}$} & \multirow{2}{*}{$\begin{array}{l}\text { Standardize } \\
\text { d } \\
\text { Coefficients } \\
\text { Beta }\end{array}$} & \multirow[b]{2}{*}{ 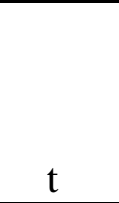 } & \multirow[b]{2}{*}{ Sig. } \\
\hline & & B & Std. Error & & & \\
\hline & (Constant) & 2,396 & 470 & & 5,100 & 000 \\
\hline & $\begin{array}{l}\text { Differentiati } \\
\text { on }\end{array}$ & , 163 & ,049 &, 181 & 3,347 &, 001 \\
\hline & Satisfaction & ,318 & ,037 & ,466 & 8,609 & ,000 \\
\hline & Quality &, 144 &, 043 &, 176 & 3,341 &, 001 \\
\hline
\end{tabular}

a. Dependent Variable: Word of Mouth Marketing

Pengaruh unsur differentiation, satisfaction dan quality terhadap word of mouth marketing dilandasi pada teori dan penelitian beberapa ahli, antara lain :

1) Lovett, J et.al (2013), Hill (2010) menemukan bahwa brand characteristic berpengaruh terhadap word of mouth, namun pada penelitian ini terdapat satu perbedaan, dimana pada penelitian ini satisfaction berpengaruh paling signifikan, sedangkan penelitian Lovett, J.et.al(2013) menunjukkan bahwa terdapat pengaruh yang positif dan signifikan dari brand characteristics pada word of mouth kecuali pada karakteristik kepuasan

2) Christoph Fuchs dan Adamantios Diamantopoulos (2010), Mangold, W. Glynn. (1999) menemukan bahwa brand characteristic berpengaruh terhadap word of mouth 
Melalui hasil penelitian ini secara simultan unsur differentiation, satisfaction dan quality berpengaruh terhadap word of mouth marketing, hal ini mendukung hipotesis (H4). Sedangkan secara parsial, hasil penelitian ini menunjukkan kesamaan dengan penelitian terdahulu yaitu : bahwa terdapat pengaruh yang signifikan dari differentiation terhadap word of mouth marketing, karena nilai signifikansinya $0,001<0,05$ berarti mendukung hipotesis $(\mathrm{H} 1)$. Untuk variabel satisfaction nilai signifikansinya $0,000<0,05$, berarti terdapat pengaruh yang signifikan satisfaction terhadap word of mouth marketing sehingga mendukung hipotesis (H2). Untuk variabel quality menunjukkan hasil signifikansinya 0,001 $<0,05$ berarti terdapat pengaruh antara quality terhadap word of mouth marketing, berarti hal ini tidak mendukung hipotesis (H3)

\section{KESIMPULAN}

Berdasarkan hasil penelitian dan analisis yang telah dilakukan maka dapat disimpulkan sebagai berikut:

1. Terdapat pengaruh secara bersama-sama differentiation, satisfaction dan quality terhadap word of mouth marketing, karena nilai signifikansinya $0,000<0,05$, hal ini mendukung hipotesis (H1).

2. Terdapat pengaruh yang signifikan dari differentiation terhadap word of mouth marketing, karena nilai signifikansinya $0,001<0,05$ berarti mendukung hipotesis $(\mathrm{H} 2)$.

3. Terdapat pengaruh yang signifikan dari satisfaction terhadap word of mouth marketing karena nilai signifikansinya $0,000<0,05$, berarti mendukung hipotesis $(\mathrm{H} 3)$.

4. Terdapat pengaruh yang signifikan dari quality terhadap word of mouth marketing karena nilai signifikansinya $0,001<0,05$, berarti mendukung hipotesis $(\mathrm{H} 4)$.

\section{SARAN}

Berdasarkan hasil penelitian dan analisis dan kesimpulan yang telah dilakukan maka saran yang dapat dilakukan sebagai berikut:

1. Pihak universitas harus memperhatikan kinerja staf pengajar / dosennya, karena mereka merupakan ujung tombak bagi universitas dalam memperoleh persepsi yang positif atas universitas yang bersangkutan, hal ini dapat dilakukan dengan memberikan pelatihan dan seminar pendidikan bagi para dosen dalam rangka mengembangkan kualitas staf pengajarnya.

2. Penelitian ini dapat dikembangkan lagi dengan menambah variabel lain yang juga berpengaruh pada word of mouth marketing, maupun responden penelitian pada wilayah yang berbeda.

\section{Ucapan Terima Kasih}

Kepada Direktur dan Staff DPPM Universitas Tarumanagara yang telah memberikan dukungan sehingga penelitian ini terselesaikan.

\section{Referensi}

Berger, Jonah dan Schwartz, Eric. (2011). “What Do People Talk About? Drivers of Immediate and Ongoing Word-of-Mouth”. Journal of Marketing Research article Postprint.

Bruyn, Arnaud De dan Lilien, Gary L. (2008). "A Multi-Stage Model of Word-of-Mouth Influence through Viral Marketing”. International Journal of Research in Marketing: 151-163. 
Buttle, Francis A. (1998). “Word of Mouth: Understanding and Managing Referral Marketing”. Journal of Strategic Marketing 6: 241-254.

Casielles, Rodolfo Vasques. (2013). "The Word of Mouth Dynamic: How Positive (and Negative) WOM Drives Purchase Probability”. Journal of Advertising Research: 43-60.

Cheema, Amar, Kaikati dan Andrew M. (2010). "The Effect of Need for Uniqueness on Word of Mouth”. Journal of Marketing Research Vol. XLVII (June 2010): 553-563.

Fuchs, Christoph dan Diamantopoulos, Adamantios. (2010). "Evaluating The Effectiveness of Brand-Positioning Strategies from a Consumer Perspective”. European Journal of Marketing Vol.44 No. 11/12, 2010: 1763-1786

Gremler, Dwayne D. (2001). "Generating Positive Word-of-Mouth Communication Through Customer-Employee Relationships". International Journal of Service Industry Management, Vol. 12 No. 1, 2001: 44-59.

Hill. (2010).'The Renaissance of Word-of-Mouth Marketing: A'New'StandardBasic Marketing. New York: Mcgraw-Hill.

Kozinets, Robert V. (2010). "Networked Narratives: Understanding Word-of-Mouth Marketing in Online Communities”. Journal of Marketing Vol.74 (march2010): 71-89.

Lovett, Mitchell J. Renana Peres, and Ron Shachar (2013). "On brands and Word of Mouth". Journal of Marketing Research Vol.L (August 2013): 427-444

Mangold, W. Glynn. (1999). "Word-of-mouth Communication in The Service Marketplace”. Journal of Service Marketing Vol. 13: 73-89.

Meiners, Norbert (2009) in Twenty-first Century Marketing Management?!’. International Journal of Economic Sciences and Applied Research 3(2): 79-97.

Palmer, Adrian. (2011). Principle of Service Marketing. Berkshire: Mcgraw-Hill Education. 